\title{
Frontal Sinus Squamous Cell Carcinoma
}

National Cancer Institute

\section{Source}

National Cancer Institute. Frontal Sinus Squamous Cell Carcinoma. NCI Thesaurus. Code C6067.

A squamous cell carcinoma that arises from the mucosal epithelial surface of the frontal sinus. Patients may present with nasal fullness, obstruction, and/or epistaxis. 